\title{
Estabelecimento de alecrim-pimenta in vitro
}

\author{
Andréa S da Costa ${ }^{1}$; Maria de Fátima Arrigoni-Blank ${ }^{1}$; Arie F Blank ${ }^{1}$; Aline B de Mendonça ${ }^{1}$; Verônica F \\ Amancio $^{1}$; Ana da S Ledo ${ }^{2}$
}

${ }^{1}$ UFS DEA, Av. Marechal Rondon s/n, B. Rosa Elze, 49100000 São Cristóvão SE; ${ }^{2}$ Embrapa Tabuleiros Costeiros, Av. Beira Mar, 3250 , 49025-040 Aracaju-SE; E-mail: afblank@ufs.br

\section{RESUMO}

O alecrim-pimenta (Lippia sidoides Cham.) é um arbusto nativo da região do semi-árido do nordeste brasileiro, cujo óleo essencial possui elevado valor comercial devido aos seus constituintes majoritários, o timol e o carvacrol, de potente propriedade antimicrobiana e anti-séptica. Avaliou-se os efeitos de concentrações e tempos de imersão em hipoclorito de sódio, de meios de cultivo e da utilização de antibiótico e antioxidantes no estabelecimento in vitro de alecrim-pimenta. Os experimentos foram conduzidos em delineamento inteiramente casualizado. Foram avaliadas as concentrações 0,2 ; 0,$4 ; 0,6$ e $0,8 \%$ de hipoclorito de sódio e $8 ; 12 ; 16$ e 20 minutos de imersão, em esquema fatorial $4 \times 4$; as concentrações $0 ; 50 ; 100$; 150 e $200 \mathrm{mg} \mathrm{L}^{-1}$ do antibiótico cefatoxima sódica; os meios-decultura MS, B5 e WPM; e o efeito de antioxidantes (PVP: 0,5 e $2 \mathrm{~g}$ $\mathrm{L}^{-1}$; e carvão ativado: 3 e $12 \mathrm{~g} \mathrm{~L}^{-1}$ ). A concentração de $0,8 \%$ de hipoclorito de sódio proporcionou um número significativamente maior $(\mathrm{p}<0,01)$ de folhas por broto: 1,88 . Para as demais características, não houve efeito significativo da concentração de hipoclorito de sódio: a contaminação variou de 33,7 a 50,6\%; o número de brotos formados, de 1,17 a 1,65 e, o número de folhas por explante, de 1,77 a 3,07. Apesar de não ter havido diferença significativa para os tempos de imersão, os tempos de 12 e 16 minutos tendem a proporcionar menor contaminação, enquanto o aumento de 16 para $20 \mathrm{mi}-$ nutos tende a induzir uma redução do número de brotos formados (de 1,52 para 1,22), número de folhas por explante (de 2,62 para $1,81)$ e número de folhas por brotos (de 1,70 para 1,24). A utilização de cefotaxima sódica reduziu significativamente a contaminação bacteriana $(55,23 \%$, no tratamento testemunha; $9,99 \%$, na concentração de $200 \mathrm{mg} \mathrm{L}^{-1}$ ), elevando a sobrevivência dos explantes de 0 (testemunha) para $37,32 \%$ (200 $\left.\mathrm{mg} \mathrm{L}^{-1}\right)$. Os meios-de-cultura proporcionaram resultados estatisticamente iguais. Todos os antioxidantes avaliados, mesmo nas concentrações mais baixas, reduziram a oxidação de $50 \%$ na testemunha para menos de $10 \%$. Os resultados indicam o uso de $0,8 \%$ de hipoclorito de sódio, com imersão de 16 minutos, $200 \mathrm{mg} \mathrm{L}^{-1}$ de cefotaxima sódica, os meios WPM, MS ou B5 e 3,0 $\mathrm{g} \mathrm{L}^{-1}$ de carvão ativado ou $0,5 \mathrm{~g} \mathrm{~L}^{-1}$ de PVP para o estabelecimento in vitro de segmentos nodais de alecrim-pimenta.

Palavras-chave: Lippia sidoides, planta medicinal nativa, micropropagação, controle de contaminação, oxidação.

\section{ABSTRACT \\ In vitro establishment of Lippia sidoides Cham}

Lippia sidoides Cham. is a native shrub from the semi-arid region of Northeast Brazil. Its essential oil has high commercial value, due to the major compounds thymol and carvacrol, which have strong antimicrobial and antiseptic properties. The effect of concentrations and immersion time in sodium hypochlorite, culture media, the use of antibiotic and antioxidants on in vitro establishment of $L$. sidoides were evaluated. The assays were conducted in a completely randomized design. We evaluated the concentrations $0.2 ; 0.4 ; 0.6$ and $0.8 \%$ of sodium hypochlorite and $8 ; 12 ; 16$ and 20 minutes of immersion, in a $4 \times 4$ factorial scheme; the concentrations 0 ; 50; 100; 150 and $200 \mathrm{mg} \mathrm{L}^{-1}$ of cefotaxime sodium; the medium cultures MS, B5 and WPM; and the effect of antioxidants (PVP: 0.5 and $2 \mathrm{~g}$ $\mathrm{L}^{-1}$; and activated charcoal: 3 and $\left.12 \mathrm{~g} \mathrm{~L}^{-1}\right)$. The concentration of $0.8 \%$ of sodium hypochlorite resulted in a significantly higher $(\mathrm{p}<0.01)$ number of leaves per shoot: 1.88. For the other characteristics we did not observe any significant effect of sodium hypochlorite concentrations: the contamination varied from 33.7 to $50.6 \%$; the number of new shoots varied from 1.17 to 1.65 , and the number of leaves per explant varied from 1.77 to 3.07. Although we did not observe significant difference for immersion times, 12 and 16 minutes of immersion tend to result in minor contamination. Increasing the immersion time from 16 to 20 minutes tends to induce a reduction of new shoots (form 1.52 to 1.22), number of leaves per explant (from 2.62 to 1.81) and number of leaves per shoot (from 1.70 to 1.24$)$. The use of cefotaxime sodium reduced significatively the bacterial contamination (55.23\% at the control treatment; $9.99 \%$ at the $200 \mathrm{mg} \mathrm{L}^{-1}$ concentration), increasing the survival of explants from 0 (control) to $37.32 \%$ ( $\left.200 \mathrm{mg} \mathrm{L}^{-1}\right)$. The medium cultures offered statistically identical results. All the evaluated antioxidants, even at the lowest concentrations, reduced the oxidation from $50 \%$ (control) to as little as $10 \%$. For in vitro establishment of $L$. sidoides nodal segments, the results indicate immersion of explants for 16 minutes in a $0.8 \%$ sodium hypochlorite solution, $200 \mathrm{mg} \mathrm{L}^{-1}$ of cefotaxime sodium, WPM, MS or B5 culture medium, and $3.0 \mathrm{~g} \mathrm{~L}^{-1}$ of activated charcoal or $0.5 \mathrm{~g} \mathrm{~L}^{-1}$ of PVP.

Keywords: Lippia sidoides, native medicinal plant, micropropagation, contamination control, oxidation.

\section{(Recebido para publicação em 25 de janeiro de 2006; aceito em 13 de abril de 2007)}

$\mathrm{O}$ gênero Lippia consiste em aproximadamente 200 espécies de ervas, arbustos pertencentes à família Verbenaceae (Terblanché \& Kornelius, 1996). Entre as espécies nativas do nordeste brasileiro e de importância econômica, destaca-se a Lippia sidoides, vulgarmente conhecida como alecrim- pimenta, alecrim-do-nordeste, alecrimbravo e estrepa-cavalo (Innecco et al., 2000; Matos, 2002). É um arbusto caducifólio, ereto, muito ramificado e quebradiço, que mede 2-3 m de altura. Suas folhas apresentam forte cheiro picante e as flores são pequenas, esbranquiçadas, reunidas em espigas de eixo curto nas axilas das folhas. É propagada por estaquia utilizando, de preferência, os ramos mais finos (Matos, 2000; Matos, 2002; Lorenzi \& Matos, 2002). As folhas e flores constituem a parte medicinal desta planta. Seu óleo essencial possui elevado valor comercial, pois contém timol ou uma mistura de timol e carvacrol, 
dois terpenos fenólicos com fortíssima propriedade antimicrobiana e anti-séptica (Matos, 2000).

Por seu valor medicinal, tornou-se importante estudar formas de propagação comercial para esta espécie, incluindo a micropropagaçao. Porém, para desenvolvimento de protocolos de micropropagação de uma dada espécie, é necessário primeiro estabelecê-la in vitro. Espécies nativas e lenhosas apresentam certa dificuldade no estabelecimento, em decorrência principalmente da oxidação e da contaminação (Sato et al., 2001). O elevado grau de contaminação e a presença sistêmica de microorganismos são responsáveis, às vezes, pelo insucesso do estabelecimento de uma cultura in vitro. $\mathrm{Na}$ desinfestação do explante, a maior dificuldade é obtê-lo descontaminado, sem conduzi-lo à morte quando isolado. Para isso, várias substâncias com ação germicida têm sido utilizadas, como o etanol e os compostos a base de cloro, tais como o hipoclorito de sódio e de cálcio (Grattapaglia \& Machado, 1998). Em amoreira-preta (Rubus sp.), a contaminação dos explantes foi reduzida com a imersão em solução de hipoclorito de sódio $(\mathrm{NaOCl})$ a $0,5 \%$ em diferentes tempos de imersão $(0,10,20$ e 30 minutos) (Augusto \& Biasi, 2002). Em Lippia integrifolia, obteve-se $24 \%$ de contaminação utilizando solução de $\mathrm{NaOCl}$ a $1,2 \%$ por 30 minutos (Passera \& Ambrosetti, 1999). Em L. junelliana (Mold.) Tronc., o controle da contaminação foi obtido com $10 \%$ de $\mathrm{NaOCl}$ por 10 minutos (Juliani Júnior et al., 1999).

A contaminação bacteriana interfere negativamente no estabelecimento de explantes in vitro. As bactérias constituem o mais comum e problemático tipo de contaminação por microrganismos em cultura de tecidos porque podem ser sistêmicas e sua detecção muitas vezes é difícil. Para evitar ou amenizar a contaminação bacteriana, antibióticos têm sido adicionados aos meios-de-cultura, combinados ou não com tratamentos dos explantes em banhos de soluções antibactericidas sob agitação, durante determinado período. Os antibióticos mais utilizados em cultura de tecidos vegetais possuem ação bacteriostática e não propriamente bactericida (Grattapaglia \& Machado, 1998).
Plantas lenhosas apresentam também dificuldades no estabelecimento in vitro, principalmente devido à oxidação que ocorre em função da liberação de compostos fenólicos. O acúmulo de polifenóis e produtos da oxidação como melanina, suberina, lignina, cutina e calose em torno da superfície excisada, modificam a composição do meio de cultivo e dificultam a absorção de metabólitos (Andrade et al., 2000). O uso de antioxidantes é uma das alternativas para contornar este problema. Estes podem ser incorporados ao meio-decultura, a exemplo do ácido ascórbico, ácido cítrico, carvão ativado, polivinilpirrolidona (PVP), cisteína, rosmanol e ditiotreitol, ou utilizados como solução para enxaguar explantes isolados evitando o processo de escurecimento (Pasqual et al., 1997). O carvão ativado evita o acúmulo de inibidores fenólicos, contudo, o seu uso pode adsorver outras substâncias do meio nutritivo, como os reguladores de crescimento, bem como pode ser tóxico a alguns tecidos. A adição de $100 \mathrm{mg} \mathrm{L}^{-1}$ de carvão ativado no meio evitou a oxidação fenólica e aumentou a produção de brotos sadios e normais em Gymnema sylvestre. Acima dessa concentração os brotos ficaram vitrificados (Rao \& Komalavalli, 2000). O PVP é um outro antioxidante que tem sido bastante empregado, pois ele também evita a oxidação dos explantes pelas enzimas fenolases, adsorvendo os produtos da oxidação fenólica ou quinonas (Pasqual et al., 1997). Augusto \& Biasi (2002) controlaram a oxidação de amoreira-preta (Rubus sp.) com a adição de $1 \mathrm{~g} \mathrm{~L}^{-1}$ PVP solúvel no meio sólido.

Este trabalho teve como objetivo o estabelecimento in vitro de alecrim-pimenta, a partir do estudo da influência de concentrações de hipoclorito de sódio e tempos de imersão, em diferentes meios de cultivo. Estudou-se também o efeito da utilização do antibiótico cefotaxima sódica e de antioxidantes no desenvolvimento dos explantes.

\section{MATERIAL E MÉTODOS}

Os experimentos foram realizados no Laboratório de Cultura de Tecidos e
Melhoramento Vegetal da Universidade Federal de Sergipe. Segmentos nodais foram retirados de plantas com três meses de idade cultivadas em casade-vegetação e pulverizados com $4 \mathrm{~g} \mathrm{~L}^{-1}$ de benomyl dois dias antes da inoculação dos explantes in vitro. Estes segmentos foram lavados em água corrente por 30 minutos e, em câmara de fluxo laminar, foram desinfestados em álcool etílico $70 \%$ durante 30 segundos e em solução de hipoclorito de sódio $(\mathrm{NaOCl})$, sob diferentes concentrações e tempos de imersão. Os explantes foram inoculados em frascos de $250 \mathrm{~mL}$, com $25 \mathrm{~mL}$ de meio de cultura MS (Murashige \& Skoog, 1962), contendo $7 \mathrm{~g} \mathrm{~L}^{-1}$ de ágar e $\mathrm{pH}$ ajustado em 5,7 \pm 0,1 antes da autoclavagem $\left(121 \pm 1^{\circ} \mathrm{Ce}\right.$ 1,05 atm, por 15 minutos). Após a inoculação as culturas foram mantidas em BOD na ausência de luz por um período de sete dias, à temperatura de $25^{\circ} \mathrm{C}$. Em seguida, foram transferidas para sala de crescimento com fotoperíodo de 16 horas de luz, temperatura de $25 \pm 2^{\circ} \mathrm{C}$ e intensidade luminosa de $30 \mathrm{mmol} \mathrm{m}^{-2} \mathrm{~s}^{-1}$.

\section{Concentrações de hipoclorito de sódio e tempos de imersão}

O delineamento experimental foi inteiramente casualizado, em esquema fatorial $4 \times 4$, sendo quatro concentrações de hipoclorito de sódio $(0,2 ; 0,4 ; 0,6$ e $0,8 \%)$ e quatro tempos de imersão $(8 ; 12$; 16 e 20 minutos), com quatro repetições, cada repetição constituída por um frasco com três explantes. Após 30 dias da inoculação, avaliou-se a contaminação (\%), o número de brotos formados, o número de folhas por broto e número de folhas por explante. Os dados obtidos foram submetidos à análises de variância pelo teste $\mathrm{F}$ e, quando significativo, foi aplicada regressão polinomial.

A partir dos resultados deste ensaio, a assepsia utilizada para os ensaios posteriores foi enxágüe dos explantes em água corrente por 30 minutos, seguido de desinfestação em câmara de fluxo laminar primeiro com álcool etílico $70 \%$, durante 30 segundos, e, depois, com solução de hipoclorito de sódio $0,8 \%$, com quatro gotas de detergente neutro, por 16 minutos. Ao final, os explantes foram lavados três vezes com água destilada e autoclavada. 
Tabela 1. Oxidação, contaminação bacteriana e sobrevivência de explantes de alecrim-pimenta in vitro, em função de concentrações de cefatoxima sódica no meio-de-cultura MS modificado. (Oxidation, bacterial contamination and survival of in vitro explants of $L$. sidoides, as a result of cefotaxime sodium concentrations in a modified MS medium culture). São Cristóvão, UFS, 2005.

\begin{tabular}{lccc}
\hline $\begin{array}{l}\text { Cefatoxima } \\
\left(\mathbf{m g ~ L}^{-1}\right)\end{array}$ & Oxidação (\%) & $\begin{array}{r}\text { Contaminação } \\
\text { bacteriana (\%) }\end{array}$ & Sobrevivência (\%) \\
\hline 0 & 28,52 & 55,23 & 0,00 \\
50 & 61,09 & 22,69 & 0,00 \\
100 & 60,39 & 34,55 & 0,52 \\
150 & 70,34 & 12,49 & 1,73 \\
200 & 42,27 & 9,99 & 37,32 \\
CV $(\%)$ & 29,11 & 53,93 & 90,51 \\
\hline \multirow{2}{*}{ Equação $(\mathrm{Y}=)$} & $-0,0018 \times 2+0,41 \times+32,77$ & $-0,13 \times+43,69$ & $0,0016 \times 2-0,17 x+1,79$ \\
\hline
\end{tabular}

\section{Concentrações de cefotaxima sódica}

Em virtude da alta taxa de contaminação bacteriana apresentada por esta espécie em testes preliminares, avaliouse a eficiência da cefatoxima sódica. $\mathrm{O}$ delineamento experimental foi o inteiramente casualizado, com cinco tratamentos $\left(0 ; 50 ; 100 ; 150\right.$ e $\left.200 \mathrm{mg} \mathrm{L}^{-1}\right)$ e cinco repetições, sendo cada repetição constituída por quatro frascos, cada frasco contendo dois explantes. $\mathrm{O}$ meio-decultura utilizado foi o MS modificado, utilizando-se metade da concentração do nitrato de amônio e 1/4 da solução de Fe-EDTA. Em câmara de fluxo laminar contínuo, o antibiótico foi filtrado a frio (0,22 $\mathrm{mm})$ e adicionado ao meio-de-cultura quando este estava em processo de resfriamento $\left(40\right.$ a $\left.50^{\circ} \mathrm{C}\right)$. Após 30 dias foram avaliadas a oxidação (\%), a contaminação bacteriana (\%) e a sobrevivência dos explantes (\%). Os dados de porcentagem foram transformados em arco seno da raiz quadrada de $(\mathrm{X} / 100)$ e submetidos à análise de variância pelo teste F. Quando a diferença entre tratamentos foi significativa, aplicou-se regressão polinomial.

\section{Meios-de-cultura}

A fim de se obter um melhor crescimento dos explantes, foram testados três meios de cultura: MS (Murashige \& Skoog, 1962), B5 (Gamborg et al., 1968) e WPM (Lloyd \& McCown, 1980). O delineamento foi inteiramente casualizado, com cinco repetições, sendo cada repetição constituída por quatro frascos contendo dois explantes. Em todos os tratamentos foi adicionado, em câmara de fluxo laminar contínuo, 200 $m g \mathrm{~L}^{-1}$ de cefotaxima sódica filtrada a frio $(0,22 \mathrm{~mm})$, para controle da contaminação por bactérias. Após 30 dias avaliaram-se a oxidação (\%), a sobrevivência (\%), o número e comprimento dos brotos formados (cm), o número de folhas e enraizamento (\%). Os dados foram submetidos à análise de variância pelo teste F. Quando o teste foi significativo, as médias foram comparadas pelo teste de Duncan $(\mathrm{p}<0,05)$.

\section{Antioxidantes}

A fim de reduzir a alta taxa de oxidação fenólica observada nesta espécie em testes preliminares, implantou-se um ensaio no delineamento experimental inteiramente casualizado com cinco tratamentos, testemunha (meio-de-cultura sem antioxidante), $\operatorname{PVP}\left(0,5\right.$ e $\left.2 \mathrm{~g} \mathrm{~L}^{-1}\right) \mathrm{e}$ carvão ativado (3 e $12 \mathrm{~g} \mathrm{~L}^{-1}$ ), com quatro repetições, sendo cada repetição constituída por quatro frascos, cada frasco contendo dois explantes. Os antioxidantes foram adicionados ao meio MS antes da esterilização. Após 30 dias foram avaliadas a oxidação (\%), o comprimento dos brotos formados (cm), a sobrevivência (\%) e a vitrificação (\%). Os dados de porcentagem foram transformados em arco seno da raiz quadrada de (X/100) e submetidos à análise de variância pelo teste $\mathrm{F}$. Quando houve diferença estatística significativa, as médias foram comparadas pelo teste de Duncan $(\mathrm{p}<0,05)$.

\section{RESULTADOS E DISCUSSÃO}

Concentrações de hipoclorito de sódio e tempos de imersão
Para as características contaminação, número de brotos formados e número de folhas por explante não houve diferença significativa em função dos fatores testados. A contaminação variou de 33,7 a 50,6, o número de brotos formados variou entre 1,17 e 1,65 e o número de folhas por explante, entre 1,77 e 3,07. A concentração de $0,8 \%$ de hipoclorito de sódio proporcionou um número significativamente maior $(\mathrm{p}<0,01)$ de folhas por broto $(\mathrm{y}=0,021 \mathrm{x}$ $+1,019, R^{2}=0,97$ ), sugerindo que essa concentração permitiu o desenvolvimento e crescimento dos explantes e que o aumento da concentração de hipoclorito de sódio resultou no aumento do número de folhas por brotos.

Apesar de não terem sido observadas diferença significativa para os tempos de imersão, observou-se que os tempos de 12 e 16 minutos tenderam a proporcionar uma menor porcentagem de contaminação, enquanto que o aumento de 16 para 20 minutos tende a induzir uma redução do número de brotos formados, de 1,52 para 1,22, respectivamente; número de folhas por explante, de 2,62 para 1,81; e número de folhas por brotos, de 1,70 para 1,24. Resultados semelhantes foram obtidos para Ananas comosus, utilizando-se a concentração de hipoclorito de sódio de 0,5 a $1,0 \%$ por 10 a 20 minutos (Teixeira et al., 2001). Já para Lippia micromera Schau. in DC. var. helleri (Britt), a desinfestação foi obtida com solução de hipoclorito a $2 \%$, por 15 minutos (Capote et al.,1999).

Concentrações de cefotaxima sódica

A utilização do antibiótico cefotaxima proporcionou um efeito positivo no controle do crescimento bacteriano e sobrevivência de explantes de alecrim-pimenta (Tabela 1). A concentração de $200 \mathrm{mg} \mathrm{L}^{-1}$ foi a mais efetiva, proporcionando uma maior sobrevivência de explantes e menor crescimento bacteriano. Porém nesta concentração houve uma maior oxidação dos explantes $(42,27 \%)$ em relação ao controle. Resultado semelhante com relação ao controle bacteriano foi obtido por Nannetti (1994) ao utilizar a mesma concentração do antibiótico na micropropagação de Heliconia sp. e por Santos (2000), no cultivo in vitro de 
Tabela 2. Número e comprimento dos brotos formados, número de folhas, oxidação, enraizamento e sobrevivência de alecrim-pimenta, em função de diferentes meios de cultivo. (Number and length of new shoots, number of leaves, oxidation, rooting and survival of $L$. sidoides, as a result of different medium cultures). São Cristóvão, UFS, 2005.

\begin{tabular}{lcccccc}
\hline Meios & $\begin{array}{c}\text { Número de } \\
\text { brotos }\end{array}$ & $\begin{array}{c}\text { Comprimento } \\
\text { dos brotos }(\mathbf{c m})\end{array}$ & $\begin{array}{c}\text { Número de } \\
\text { folhas }\end{array}$ & $\begin{array}{c}\text { Oxidação (\%) } \\
\text { Enraizamento (\%) }\end{array}$ & $\begin{array}{c}\text { Sobrevivência } \\
\text { (\%) }\end{array}$ \\
\hline WPM & $2,83 \mathrm{a}$ & $0,670 \mathrm{a}$ & $15,57 \mathrm{a}$ & $17,00 \mathrm{a}$ & $15,00 \mathrm{a}$ & $37,50 \mathrm{a}$ \\
MS & $2,23 \mathrm{a}$ & $0,484 \mathrm{a}$ & $11,07 \mathrm{a}$ & $30,00 \mathrm{a}$ & $7,50 \mathrm{ab}$ & $37,50 \mathrm{a}$ \\
B5 & $1,47 \mathrm{a}$ & $0,358 \mathrm{a}$ & $9,10 \mathrm{a}$ & $15,00 \mathrm{a}$ & $0,00 \mathrm{~b}$ & $17,50 \mathrm{a}$ \\
\hline CV (\%) & 46,54 & 47,78 & 46,95 & 105,64 & 117,85 & 51,28 \\
\hline
\end{tabular}

* Médias seguidas de mesma letra nas colunas não diferem entre si pelo teste de Duncan, $\mathrm{p} \leq 0,05$ (Means followed by the same letter in the column do not differ from each other by the Duncan's test, $\mathrm{p} \leq 0,05)$.

Heliconia pssittacorum Sessé \& Moc. Em sementes de aipo, berinjela, cebola e tomate, bem como, gemas axilares de mandioca in vitro, a concentração de 100 mg L ${ }^{-1}$ de cefotaxima sódica controlou a contaminação bacteriana (Cid \& Durzan, 2003).

\section{Meios-de-cultura}

Não houve efeito significativo dos meios-de-cultura sobre as características analisadas, exceto para a porcentagem de enraizamento (Tabela 2). O meio-de-cultura WPM proporcionou um maior enraizamento dos explantes em relação ao meio B5. Para esta característica os meios de cultura MS e WPM proporcionaram resultados estatisticamente iguais (Tabela 2). De forma geral, os meios de cultura MS, WPM e B5 proporcionaram resultados estatisticamente iguais, porém optou-se pela utilização do meio MS para multiplicação in vitro de $L$. sidoides por ser o meio padrão mais empregado na cultura de tecidos.

No estabelecimento in vitro o meiode-cultura é um fator importante para o desenvolvimento dos explantes e varia de acordo com a espécie ou, até mesmo, entre genótipos. Desta maneira, para o estabelecimento in vitro de Prunus insititia L. (Andrei \& Marin, 2005) e Vitis thunbergii Sieb. et. Zucc. (Lu, 2005), o meio WPM foi melhor. Huimei et al. (2005) observaram que os meios WPM e B5 foram mais efetivos na regeneração de Camptotheca acuminata e, em porta-enxerto de videira "420-A", o meio MS promoveu um maior crescimento das brotações no seu cultivo inicial (Dzazio et al., 2002). Em amendoeira o meio AP (Almehdi \& Parfitt, 1986) promoveu o melhor estabelecimento da cultivar Nonpariel e, o meio

Tabela 3. Oxidação, comprimento dos brotos formados, sobrevivência e vitrificação de alecrim-pimenta em função de diferentes concentrações de dois antioxidantes. (Oxidation, length of new shoots, survival and vitrification of $L$. sidoides, as a result of different concentrations of two antioxidants). São Cristóvão, UFS, 2005.

\begin{tabular}{lrccc}
\hline Tratamentos & Oxidação (\%) & $\begin{array}{c}\text { Comprimento } \\
\text { dos brotos } \\
\text { formados }(\mathbf{c m})\end{array}$ & $\begin{array}{c}\text { Sobrevivência } \\
\mathbf{( \% )}\end{array}$ & $\begin{array}{c}\text { Vitrificação } \\
\text { (\%) }\end{array}$ \\
\hline Testemunha & $50,00 \mathrm{a}$ & $0,63 \mathrm{~b}$ & $2,69 \mathrm{c}$ & $0,00 \mathrm{~b}$ \\
$0,5 \mathrm{~g} \mathrm{~L}^{-1} \mathrm{PVP}$ & $8,49 \mathrm{~b}$ & $2,37 \mathrm{a}$ & $50,00 \mathrm{ab}$ & $0,00 \mathrm{~b}$ \\
$2,0 \mathrm{~g} \mathrm{~L}^{-1} \mathrm{PVP}$ & $3,23 \mathrm{~b}$ & $2,36 \mathrm{a}$ & $80,97 \mathrm{a}$ & $59,64 \mathrm{a}$ \\
$3,0 \mathrm{~g} \mathrm{~L}^{-1}$ carvão & $1,70 \mathrm{~b}$ & $1,83 \mathrm{a}$ & $40,36 \mathrm{ab}$ & $21,57 \mathrm{a}$ \\
$12,0 \mathrm{~g} \mathrm{~L}^{-1}$ carvão & $0,00 \mathrm{~b}$ & $2,62 \mathrm{a}$ & $37,06 \mathrm{~b}$ & $25,00 \mathrm{a}$ \\
\hline $\mathrm{CV}(\%)$ & 77,28 & 34,44 & 41,77 & 77,93 \\
\hline
\end{tabular}

* Médias seguidas de mesma letra nas colunas não diferem entre si pelo teste de Duncan, $\mathrm{p}$ $\leq 0,05$ (Means followed by the same letter in the column do not differ from each other by the Duncan's test, $\mathrm{p} \leq 0,05)$.

MS, para a cultivar Ne Plus Ultra (Channuntapipat et al., 2003). Em aceroleira (Malpighia emarginata DC.), os meios WPM e DKW (Driver \& Kuniyuki,1984) favoreceram um maior número de brotações no cultivo in vitro dos genótipos IPA-2, IPA-3 e IPA-4, sendo que IPA-3 teve maior potencial de multiplicação (Melo et al., 1999).

\section{Antioxidantes}

Houve diferenças significativas entre a presença e ausência de antioxidantes para todas as características analisadas, exceto para vitrificação, que, ao utilizar $0,5 \mathrm{~g} \mathrm{~L}^{-1}$ de PVP, não ocorreu (Tabela 3). Já entre as diferentes concentrações dos antioxidantes (PVP e carvão ativado), não houve diferenças significativas, ambos sendo eficientes no controle da oxidação (Tabela 3). O carvão ativado, na concentração de $12,0 \mathrm{~g} \mathrm{~L}^{-1}$, controlou $100 \%$ da oxidação dos explantes (Tabela 3). Na regeneração in vitro de embriões de coqueiro anão (Cocos nucifera L.), o uso de $2,5 \mathrm{~g} \mathrm{~L}^{-1}$ de carvão ativado no meio- de-cultura mostrou-se eficiente na eliminação do escurecimento causado pela oxidação (Silva, 2002), enquanto que na micropropagação de biribá (Rollinia mucosa Jacq Baill), a utilização de 0,5 $\mathrm{g} \mathrm{L}^{-1}$ de PVP foi eficiente no controle da oxidação (Figueiredo et al., 2001). Já para o estabelecimento de embriões de guarirobeira (Syagrus oleracea (MART.) BECC.) o PVP a 0,4 g L ${ }^{-1}$ não foi eficiente (Melo et al., 2001).

Apesar dos resultados obtidos com 0,5 $\mathrm{g} \mathrm{L}^{-1}$ de PVP, ausência de vitrificação e boa sobrevivência dos explantes, em relação à concentração de $3,0 \mathrm{~g} \mathrm{~L}^{-1}$ de carvão ativado, optou-se pelo uso de $3,0 \mathrm{~g} \mathrm{~L}^{-1}$ de carvão ativado para a multiplicação de L. sidoides devido ao menor custo.

Ao longo do período de estabelecimento de L. sidoides observou-se diferença marcante em relação às diferentes épocas do ano. A época seca, quando a umidade relativa do ar é menor, favorece o estabelecimento. $\mathrm{Na}$ época chuvosa ocorreu uma maior incidência de microorganismos, principalmente 
bactérias endógenas, além da oxidação, sendo necessário, durante esse período, a utilização de antibióticos e antioxidantes no meio de cultivo. Neste ensaio, implantado no mês de setembro, o controle apresentou $50 \%$ de oxidação. Resultados similares foram encontrados em explantes de maçã cv. Tydeman's Early Worcester, em que a menor oxidação ocorreu no verão, enquanto nas demais estações do ano, a oxidação aumentou (Modgil et al., 1999).

Concluiu-se que a concentração de $0,8 \%$ de hipoclorito de sódio, com tempo de imersão por 16 minutos, promove uma melhor desinfestação dos explantes. Não existe diferença entre os meios de cultura quanto ao estabelecimento in vitro. A concentração de 200 $\mathrm{mg} \mathrm{L}^{-1}$ do antibiótico cefotaxima sódica controla a contaminação bacteriana. $\mathrm{O}$ carvão ativado a $3 \mathrm{~g} \mathrm{~L}^{-1}$ e o PVP a 0,5 g $\mathrm{L}^{-1}$ proporcionam baixa porcentagem de oxidação.

\section{AGRADECIMENTOS}

Os autores agradecem à CAPES pela bolsa do primeiro autor e ao CNPq pelo financiamento da pesquisa e pelas bolsas de produtividade do terceiro autor e de PIBIC/CNPq do quarto autor.

\section{REFERÊNCIAS}

ALMEHDI AA; PARFITT DE. 1986. In vitro propagation of peach. 1. Propagation of "Lovell" and "Nemaguard" peach rootstocks. Fruit Varieties Journal 40: 12-17.

ANDRADE MW; LUZ JMQ; LACERDA AS; MELO PRA. 2000. Micropropagação da aroeira (Myracrodruon urundeuva Fr. All). Ciência e Agrotecnologia 24: 174-180.

AUGUSTO CSS; BIASI LA. 2002. Micropropagação da amoreira-preta cv. Brazos. Scientia Agraria 3:114-114.

ANDREI P; MARÍN JA. 2005. In vitro culture establishment and multiplication of the Prunus rootstock "Adesoto 101" (P. insititia L.) as affected by the type of propagation of the donor plant and by the culture medium composition. Scientia Horticulturae 106: 258-267.

CAPOTE A; FUENTES V; BLANCO N; PEREZ O. 1999. Micropropagacion y regeneration de plantas in vitro de oreganillo Lippia micromera Schau. Revista del Jardin Botanico Nacional 20: 139-142.

CHANNUNTAPIPAT C; SEDGLEY M; COLLINS G. 2003. Micropropagation of almond cultivars Nonpareil and Ne Plus Ultra and the hybrid rootstock Titan x Nemaguard. Scientia Horticulturae 98: 473-484.

CID BLP; DURZAN DJ. 2003. Efeito da cefotaxima na germinação, crescimento $e$ brotação de gemas axilares, sob condições in vitro. Brasília: Embrapa Recursos Genéticos e Biotecnologia, 17 p. (Boletim de pesquisa e desenvolvimento, 49).

DRIVER, JA; KUNIYUKI, AH. 1984. In vitro propagation of Paradox walnut rootstock. HortScience 9: 507-509.

DZAZIO PM; BIASI LA; ZANETTE F. 2002. Micropropagação do porta-enxerto de videira "420-A". Revista Brasileira de Fruticultura 24: 759-764.

FIGUEIREDO SFL; ALBARELLO N; VIANA VRC. 2001. Micropropagation of Rollinia mucosa (jacq.) Baill. In Vitro Cell Developmental Biology Plant 37: 471-475.

GAMBORG OL; MILLER RA; OJIMA K. 1968. Nutrient requirements of suspension cultures of soybean root cells. Experimental Cell Research 50: 151-158.

GRATTAPAGLIA D; MACHADO MA. 1998. Micropropagação. In: TORRES AC; CALDAS LS; BUSO JA. (eds). Cultura de tecidos e transformação genética de plantas. Brasília: Embrapa Informação tecnológica/Embrapa Hortaliças. p. 183-260.

HUIMEI W; YUANGANG Z; FENGLI D; XIAOJU Z. 2005. Assessment of factors affecting in vitro shoot regeneration from axillary bud explant of Camptotheca acuminata. Journal of Forestry Research 16: 52-54.

INNECCO R; MATTOS SH; CRUZ GF. 2000. Determinação da altura de corte do alecrimpimenta. Horticultura Brasileira 18: 992-993.

JULIANI JUNIOR HR; KOROCH AR; JULIANI HR; TRIPPI VS. 1999. Micropropagation of Lippia junelliana (Mold.) Tronc. Plant Cell, Tissue, and Organ culture 59: 175-179.

LORENZI H; MATOS FJA. 2002. Plantas medicinais no Brasil: nativas e exóticas. Nova Odessa: Instituto Plantarum. 512 p.

LLOYD G; McCOWN B. 1980. Use of microculture for production and improvement of Rhododendron spp. HortScience 15: 416.

LU MC. 2005. Micropropagation of Vitis thunbergii Sieb. et Zucc., a medicinal herb, through high-frequency shoot tip culture. Scientia Horticulturae 107: 64-69.

MATOS FJA. 2002. Farmácias vivas: sistema de utilização de plantas medicinais projetado para pequenas comunidades. Fortaleza: UFC. 267 p. MATOS FJA. 2000. Plantas medicinais: guia de seleção e emprego de plantas usadas em fitoterapia no nordeste do Brasil. Fortaleza: UFC. 344 p.

MELO B; PINTO JEBP; LUZ JMQ; PEIXOTO JR; JULIATTI FC. 2001. Diferentes antioxidantes no controle da oxidação, germinação e desenvolvimento das plântulas na cultura in vitro de embriões de guarirobeira [Syagrus oleracea (MART.) BECC]. Ciência e Agrotecnologia 25: 1301-1306.

MELO NF; OKASAKI WY; LEITE CB; FÁRI M. 1999. Estabelecimento do cultivo in vitro da aceroleira (Malpighia emarginata DC.). Ciência e Agrotecnologia 23: 102-107.

MODGIL M; SHARMA DR; BHARDWAJ SV. 1999. Micropropagation of apple cv. Tydeman's Early Worcester. Scientia Horticulturae 81: 179-188.

MURASHIGE T; SKOOG F. 1962. A revised medium for rapid growth and bioassys with tobacco tissue cultures. Physiologia Plantarum 15: 473-479.

NANNETTI DC. 1994. Utilização da cultura de tecidos vegetais na micropropagação e manutenção de Heliconia sp. Lavras: UFLA.106p (Tese mestrado).

PASQUAL M; HOFFMANN A; RAMOS JD. 1997. Cultura de tecidos vegetais: tecnologia e aplicações - introdução: fundamentos básicos. Lavras: UFLA/FAEPE. 159 p.

PASSERA CB; AMBROSETTI JA. 1999. In vitro propagation of "Incayuyo", Lippia intergrifolia (Gris.) Hier. (Verbenaceae), a medicinal and aromatic plant of Monte Phytogeographical Province, Argentina. Acta Horticulturae 502: 319-324.

RAO MV; KOMALAVALLI N. 2000. In vitro micropropagation of Gymnema sylvestre - a multipurpose medicinal plant. Plant Cell, Tissue, and Organ Culture 67: 97-105.

SANTOS MHLC. 2000. Avaliação do efeito de bactérias promotoras de crescimento in vitro e em casa-de-vegetação de Heliconia psittacorum Sessé \& Moc. Recife: UFPe. 116p (Tese mestrado).

SATO AY, DIAS HCT, ANDRADE LA; SOUZA VC. 2001. Micropropagação de Celtis sp: controle da contaminação e oxidação. Cerne 7: 117-123.

SILVA VS. 2002. Regeneração in vitro de embrioes de Cocos nucifera $L$. Piracicaba: USPESALQ. 78p. (Tese mestrado).

TERBLANCHÉ FC; KORNELIUS G. 1996. Essential oil constituents of the genus Lippia (Verbenaceae) - A literature review. Journal of Essential Oil Research 8: 471485.

TEIXEIRA JB; CRUZ ARR; FERREIRA FR; CABRAL JRS. 2001. Biotecnologia aplicada à produção de mudas. Biotecnologia Ciência \& Desenvolvimento 19: 42-47. 